\title{
Quality of nursing care in surgery wards
}

\section{Jakość opieki pielęgniarskiej na oddziałach chirurgicznych}

\author{
Jozefa Czarnecka ${ }^{1}$, Zofia Sienkiewicz², Ewa Kobos², Andrzej Krupienicz ${ }^{1}$ \\ ${ }^{1}$ Department of Basic Nursing, Faculty of Health Sciences, Warsaw Medical University, Warsaw, Poland \\ Head of the Department: dr hab. n. med. Andrzej Krupienicz \\ ${ }^{2}$ Department of Social Nursing, Faculty of Health Sciences, Warsaw Medical University, Warsaw, Poland \\ Head of the Department: dr hab. n. med. Jacek Imiela
}

Medical Studies/Studia Medyczne 2018; 34 (1): 15-24

DOI: https://doi.org/10.5114/ms.2018.74818

Key words: surgery, nursing, patient, quality of care.

Słowa kluczowe: pacjent, jakość opieki, pielęgniarstwo, chirurgia.

\begin{abstract}
Introduction: Modern model of providing high quality of healthcare recognizes internal quality assurance system as an important task for staff management, to ensure good nursing practice that would guarantee such conditions to allow safe treatment for patient.

Aim of the research: The purpose of this study was to evaluate the quality of nursing care provided in hospitals' surgical wards with and without the ISO certificate (International Organization for Standardization) series 9001:2000 regarding quality management. The evaluation was completed by patients.

Material and methods: The research was conducted with the use of standardized questionnaire: the Hospital Consumer Assessment of Health Provider and System (HCAHPS), created by the Agency for Healthcare Research and Quality (AHRQ) in the United States. Patients treated at surgical wards in Warsaw's hospitals, completed those questionnaires distributed by the staff on the day of a patient's discharge. The study consisted of 1,000 participants.

Results: Analysis of the results showed a higher level of nursing care based on different subscales in hospitals with the certificate than in those without it. In two subscales, the differences were important statistically: nursing services $(p<0.001)$ and patient's environment $(p<0.001)$. Comparison of other subscales were not important statistically. With regards to reduced mobility, statistically significant difference was $p=0.03$, and evaluation of hospitals was $p<0.001$ and was higher for hospitals with the certificate. Conclusions: Award of the certificate to the hospital had influenced the results received from patients regarding the evaluation of nursing care. From the service-receiver stance, we could obtain information about strengths and weaknesses of nursing care.
\end{abstract}

\section{Streszczenie}

Wprowadzenie: Nowoczesny model zapewnienia wysokiej jakości opieki medycznej zakłada wewnętrzny system jakości jako ważne zadanie dla kadry kierowniczej w celu zapewnienia dobrej praktyki pielęgniarskiej, gwarantującej stworzenie warunków do bezpiecznego działania na rzecz pacjenta.

Cel pracy: Celem pracy było różnicowanie jakości opieki pielęgniarskiej przez pacjentów na oddziałach chirurgicznych w szpitalach z certyfikatem i bez certyfikatu ISO (International Organization for Standarization) serii 9001:2000 w zakresie zarządzania jakością.

Materiał i metody: W badaniu zastosowano metodę sondażu diagnostycznego z wykorzystaniem wystandaryzowanego kwestionariusza - Hospital Consumer Assessment of Health Providers and System (HCAHPS), stworzonego przez Stowarzyszenie Badań Jakości Opieki Zdrowotnej (AHRQ - Agency for Healthcare Research and Quality) w Stanach Zjednoczonych. Wzięło w nim udział 1000 pacjentów z oddziałów chirurgicznych. Ankiety były rozprowadzane wśród pacjentów bezpośrednio przez prowadzącą badanie $\mathrm{w}$ dniu wypisu chorego do domu.

Wyniki: Analiza wyników wykazała wyższy poziom opieki pielęgniarskiej na podstawie poszczególnych podskal w szpitalach z certyfikatem niż w szpitalach bez certyfikatu. W dwóch podskalach wystąpiły różnice istotne statystycznie: usługi pielęgniarskie $(p<0,001)$ oraz środowisko pacjenta $(p<0,001)$. W pozostałych podskalach różnice były nieistotne statystycznie. W zakresie ograniczonej sprawności różnica istotna statystycznie była na poziomie $p=0,03$, a w ocenie szpitali na poziomie $p<0,001$ i była wyższa dla szpitali z certyfikatem.

Wnioski: Przyznanie certyfikatu szpitalowi miało wpływ na odpowiedzi otrzymane od pacjentów oceniających opiekę pielęgniarską. Z pozycji odbiorcy świadczeń można było uzyskać informację o mocnych i słabych stronach opieki pielęgniarskiej. 


\section{Introduction}

Functioning of healthcare facility, modern team administration, and management should take into consideration the issue of patients' safety. Modern model of providing high quality of healthcare recognizes internal quality assurance system as an important task for the management of staff to ensure that good nursing practice would guarantee safe treatment of a patient. The important task for the management of staff in a modern administration and management of hospitals is to create the integrated management system (IMS) elements, consisting of: quality management system, relying on guidelines and requirements in PN-EN ISO 9001-2000 norms, environment management system (EMS), relying on guidelines in PN-EN ISO 14000 norms, and health and safety at work management system (HSWMS), relying on requirements in PN-N 18001 norm. It is commonly accepted that IMS enables organizations to meet patients' requirements, expectations, and satisfaction, based on providing good nursing practice that guarantees conditions for safe patient treatment [1-3].

The interest in quality management systems consistent with ISO 9001:2000 series norms (PN-EN ISO 9001:2009) is considered a factor encouraging healthcare institutions to introduce actions relating to safety. International Organization for Standardization (ISO) requirements and guidelines encourage institutions to control all processes for providing health and safety at work, and checking and identifying everything that could be detrimental for the patient during his stay not only in the hospital, but in all institutions where medical attention is given. Being awarded with the ISO certificate means a high level of health services provided and good organization of work [4-6].

Currently, the motivating factor for providing patients' safety in healthcare institutions is hospitals' accreditation and rating [7]. Provision of high quality nursing care is an important duty of health protecting sector. It involves checking and identifying everything that may have an adverse effect on patients' comfort. Quality in nursing care means level of patients' satisfaction with his health and healthcare received according to his needs, expectations, and desires $[8,9]$. Therefore, patients' contentment with care is influenced by following factors: time of occurrence and duration of disease, accuracy of treatment effect, satisfying health needs, quick and safe fulfilment of care, accessibility, continuation of care, performance techniques and interpersonal relationships, healthcare management and founding method, hospital's environmental conditions, and patients' sociographic factors (age, sex, marital status, etc.) [10]. Evaluation of quality from patients' point of view does not relate only to care opinion, but expresses an emotional state, described as satisfaction or dissatisfaction $[11,12]$. In an evaluation of care, a patient compares his own experiences resulting from care received with his own expectations [13, 14]. Among references in XIII National Health Programme for years 2007-2015, there is a recommendation to run and develop a research on patients' opinion $[6,15]$.

Evaluation of quality in healthcare has a particular meaning influencing patients' health and life, prevention of adverse effects, meeting patients' expectations, and growing competitiveness. Exposing strengths and weaknesses of nursing care may help to improve organizational and technical conditions, interpersonal relations between staff and patients, and efficient healthcare management. Level of nursing care in institutions managing only by internal methods of quality provisions is lower than in those institutions, which manage both internal and external methods.

\section{Material and methods}

One thousand patients treated at surgical wards in Warsaw's hospitals took part in the research (100 people from each hospital). Questionnaires were distributed among patients directly by the person leading the study on the days of a patients discharge. Questionnaires not fully completed were excluded from the analysis. The final number of the analyzed questionnaires was smaller than the number of people covered by the research and amounted to $74 \%$ (744 patients: 556 patients from hospitals with the ISO certificate and 188 patients from hospitals without the certificate).

The research applied the method of diagnostic poll using standardized questionnaire - the Hospital Consumer Assessment of Health Provider and System (HCAHPS), created by the Agency for Healthcare Research and Quality (AHRQ) in the United States.

The questionnaire (HCAHPS), titled "Patients' opinion on nursing care", was directed to patients. Its purpose was to perform evaluation of care perceived by a patient. It consisted of 24 closed questions, 19 questions were divided into 5 subscales relating to patient's experiences with care received, and resulting from: nursing services, nurses' communication, medication communication, pain management, patients' environment, and two general questions: general ward evaluation, recommendation of hospital. Other questions referred to demography.

Each of the answers given to the questions being a part of the particular subscale was given a weight (number), which higher value showed positive character of an answer and the lower showed negative one. Those values were then added up in full and given one of the three grades: good, average, or bad; division was done in proportion with total of values combined. For statistical case, study MS Excel and Statistic 8 were used together with the Cronbach's coefficient alpha, Mann Whitney's test, and Pear- 
son's $\chi^{2}$ test. A significance level was considered as $p=0.05$.

Bioethical Commission at Warsaw Medical University gave its permission $(\mathrm{KBO} / 25 / 10)$ to carry out the research.

\section{Results}

The analyzed group consisted of $N=744$ subjects, including 363 females (49\%) and 381 males (51\%), therefore, not very diverse with respect to gender. The vast majority of respondents (75\%) were treated in hospitals with the ISO 9001:2000 certificate. The detailed data are presented in Table 1.

Among respondents, the most represented groups were from the age range of 50-64 years (37\% in hospitals with the certificate and 35\% in hospitals without the certificate), and $65-80$ years (23\% both in hospitals with and without the certificate). Young people, below 35 years of age, accounted for $18 \%$ of respondents in hospitals with the certificate, and $21 \%$ in hospitals without the certificate. More than half of respondents in hospitals with the certificate (53\%) and without the certificate $(51 \%)$ had secondary level of education, and $16 \%$ in hospitals without the certificate and $21 \%$ in hospitals with the certificate had primary level of education. The remaining patients (35\% in hospitals with the certificate and 33\% in hospitals without the certificate) were educated to $1^{\text {st }}$ or $2^{\text {nd }}$ degree higher education level. Limited mobility was observed in $9 \%$ of patients in hospitals with the certificate and $4 \%$ in hospitals without the certificate.

Questions' coherence embedded in questionnaire HCAHPS, expressed as Cronbach's $\alpha$ coefficient for data in research from hospitals without the certificate, fluctuated between 0.353 and 0.385 , while in hospitals with the certificate between 0.425 and 0.911 . Results are shown in Table 2.

Patients' opinion on level of nursing care, subscale nursing services, was influenced by: way of treating a patient and promptness of care provided. Patients were always treated courteously according to $75 \%$ of respondents in hospitals with the certificate and $69 \%$ in hospitals without the certificate. Promptitude of care received after indicating it with a bell, differed in both types of hospitals. More than half of researched group of patients in hospitals with the certificate (56\%) and much smaller group in hospitals without the certificate (34\%), always received help as quickly as they needed it, whereas help was never needed in group of $41 \%$ patients in hospitals without the certificate and $28 \%$ respondents in hospitals

Table 1. Characteristics of the patient group researched

\begin{tabular}{|c|c|c|c|c|c|}
\hline \multirow[t]{2}{*}{ Data } & & \multicolumn{2}{|c|}{$\begin{array}{l}\text { Number of patients in hospitals } \\
\text { with the certificate }\end{array}$} & \multicolumn{2}{|c|}{$\begin{array}{l}\text { Number of patients in hospitals } \\
\text { without the certificate }\end{array}$} \\
\hline & & No & $\%$ & No & $\%$ \\
\hline \multirow[t]{2}{*}{ Gender } & Female & 271 & 49 & 92 & 49 \\
\hline & Male & 285 & 51 & 96 & 51 \\
\hline \multirow[t]{6}{*}{ Age } & $<24$ & 20 & 4 & 15 & 8 \\
\hline & $25-34$ & 78 & 14 & 25 & 13 \\
\hline & $35-49$ & 118 & 21 & 34 & 18 \\
\hline & $50-64$ & 204 & 37 & 65 & 35 \\
\hline & $65-80$ & 129 & 23 & 44 & 23 \\
\hline & $>80$ & 7 & 1 & 5 & 3 \\
\hline \multirow[t]{5}{*}{ Education } & Primary & 64 & 12 & 30 & 16 \\
\hline & Secondary no exams & 151 & 27 & 45 & 24 \\
\hline & Secondary with exams & 142 & 26 & 51 & 27 \\
\hline & Undergraduate & 42 & 7 & 14 & 7 \\
\hline & Postgraduate & 157 & 28 & 48 & 26 \\
\hline \multirow[t]{2}{*}{ Disability } & Yes & 51 & 9 & 8 & 4 \\
\hline & No & 505 & 91 & 180 & 96 \\
\hline Total & $N=744$ & 556 & 75 & 188 & 25 \\
\hline
\end{tabular}


Table 2. Credibility of subscales according to patient's evaluation in hospitals with and without the certificate

\begin{tabular}{|c|c|c|c|}
\hline \multirow[t]{2}{*}{ Subscales } & \multirow{2}{*}{$\begin{array}{l}\text { Description of questions being part } \\
\text { of each subscale }\end{array}$} & \multicolumn{2}{|c|}{ Cronbach's coefficient $\alpha$} \\
\hline & & $\begin{array}{l}\text { Hospitals without } \\
\text { the certificate }\end{array}$ & $\begin{array}{l}\text { Hospitals with } \\
\text { the certificate }\end{array}$ \\
\hline Nursing services & $\begin{array}{l}1 \text { - treating patient with courtesy and respect } \\
4 \text { - speed of nursing assistance received after } \\
\text { pressing the buzzer } \\
8 \text { - help with satisfying the need for defecation }\end{array}$ & 0.385 & 0.425 \\
\hline $\begin{array}{l}\text { Nursing } \\
\text { communication }\end{array}$ & $\begin{array}{l}2 \text { - nurses listened to patient with attention } \\
3 \text { - explained things understandably } \\
16 \text { - information about help available after } \\
\text { leaving the hospital } \\
17 \text { - health issues that patient should look out } \\
\text { for were explained in writing and orally }\end{array}$ & 0.592 & 0.55 \\
\hline $\begin{array}{l}\text { Communication about } \\
\text { medication }\end{array}$ & $\begin{array}{l}13 \text { - nurses understandably explained working } \\
\text { of the new medication } \\
14 \text { - clear explanation of possible side effects } \\
\text { of the new medication }\end{array}$ & 0.684 & 0.778 \\
\hline Pain management & $\begin{array}{l}10 \text { - effective pain relief therapy } \\
11 \text { - nurses monitoring the pain scale }\end{array}$ & 0.853 & 0.911 \\
\hline Patient environment & $\begin{array}{l}5 \text { - room and toilet cleanliness } \\
6 \text { - provision of silence during night hours }\end{array}$ & 0.381 & 0.429 \\
\hline
\end{tabular}

with the certificate (difference important statistically $p<0.001$ ). According to $17 \%$ respondents in hospitals without the certificate and $12 \%$ patients in hospitals with the certificate, help was provided quickly in general ( $p=0.036$ ) (Figure 1A).

The biggest group (75\% respondents in hospitals with the certificate and $61 \%$ respondents in hospitals without the certificate) always received help when going to the toilet or using the bottle as quickly as they requested ( $p=0.019$ ). Less numerous group (31\% patients in hospitals without the certificate and $15 \%$ people in hospitals with the certificate) usually received help quickly ( $p=0.033$ ) (Figure 1B).

Nursing services were evaluated as good by the most numerous group (93\% of respondents in hospitals with the certificate and $89 \%$ of respondents in hospitals without the certificate). Average grade was given by $9 \%$ of patients in hospitals without the certificate and $6 \%$ in hospitals with the certificate. The least numerous group ( $2 \%$ of respondents in both hospitals with and without the certificate) evaluated nursing services as bad.

Most of the respondents' group (69\% of patients in both types of hospitals) thought that nurses always listened to patients with attention. In opinion of $26 \%$ of respondents in hospitals with the certificate and $23 \%$ in hospitals without the certificate, nurses usually listened to patients with attention.

Nurses always explained things to a patient to understand according to $67 \%$ of respondents both in hospitals with the certificate and without the cer- tificate. In opinion of $26 \%$ of respondents in hospitals without the certificate and $25 \%$ of respondents in hospitals with the certificate, nurses usually explained things in a comprehensive way. Two per cent of respondents believed that nurses never explained things clearly.

More than half of the study group (57\% in both types of hospitals) confirmed nurses' empathy and asked patients if they would require help after leaving the hospital. According to $43 \%$ of respondents in hospitals without the certificate and with the certificate, nurses did not ask patients about what would happen to them after leaving the hospital.

The most numerous group of patients (83\% in hospitals with the certificate and $77 \%$ of respondents in hospitals without the certificate) received verbal and written information regarding symptoms and problems that can occur after leaving the hospital $(p=0.03)$. Less numerous group $(23 \%$ of people in hospitals without the certificate and $17 \%$ of patients in hospitals with the certificate) did not receive such information in writing ( $p=0.03$ ) (Figure 1C).

Nurses' communication was evaluated as good by $76 \%$ of patients in hospitals with the certificate and $72 \%$ in hospitals without the certificate. According to $25 \%$ of respondents in hospitals without the certificate and $22 \%$ of respondents in hospitals with the certificate, such communication was rated as average. Communication evaluated as bad was given by $3 \%$ of respondents in hospitals without the certificate and $1 \%$ of patients in hospitals with the certificate. 


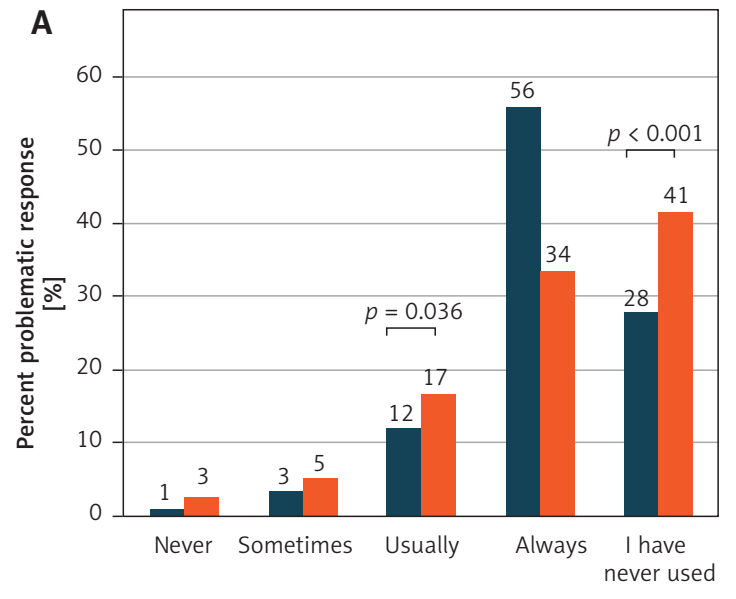

Nurses' speed in providing care

- Hospital with certificate

- Hospital without certificate

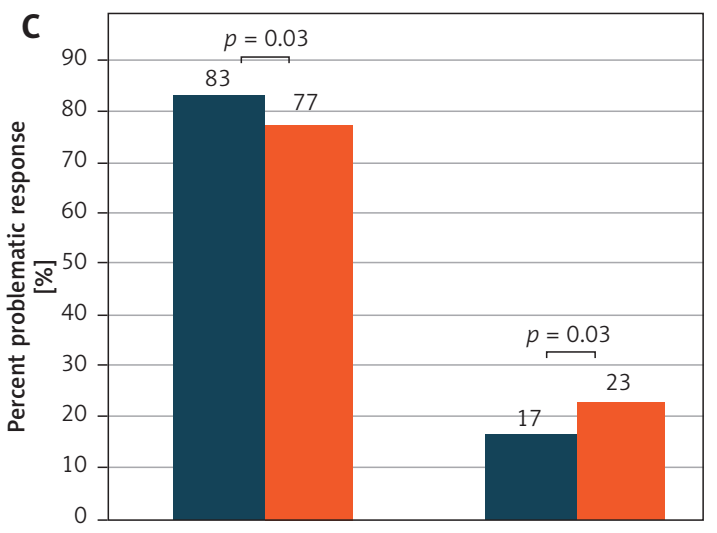

Yes

No

Oral and written information

- Hospital with certificate

- Hospital without certificate

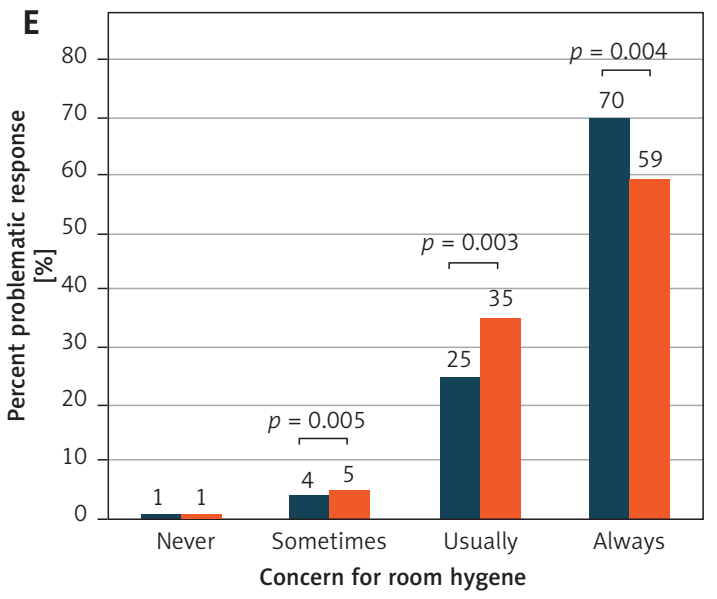

- Hospital with certificate

- Hospital without certificate

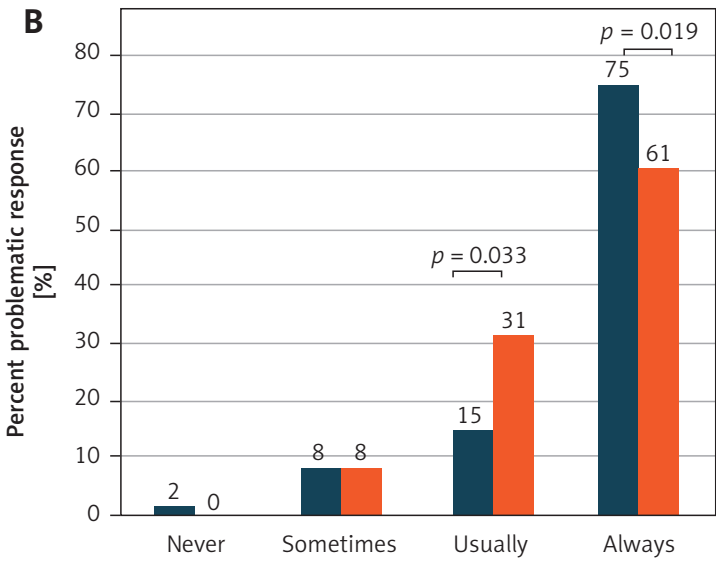

Nurses' speed in satisfying continence needs

- Hospital with certificate

- Hospital without certificate
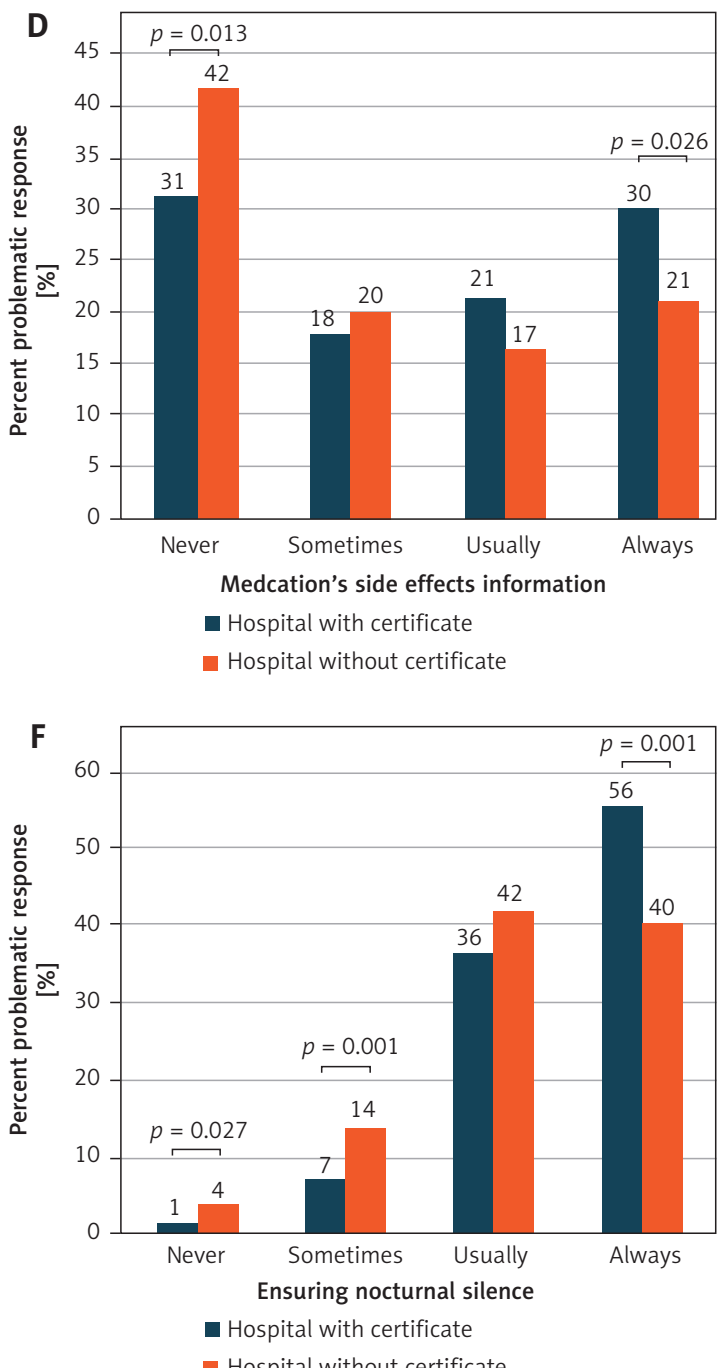

Figure 1. Level of patient's satisfaction with help speed, written information received, explanation of side effects, night time peace, and cleanliness of rooms 
Table 3. Patients' evaluation and recommendation of the hospital

\begin{tabular}{|c|c|c|c|c|c|}
\hline \multirow[t]{2}{*}{ Data } & & \multicolumn{2}{|c|}{$\begin{array}{l}\text { Number of patients in hospitals } \\
\text { with the certificate }\end{array}$} & \multicolumn{2}{|c|}{$\begin{array}{c}\text { Number of patients in hospitals } \\
\text { without the certificate }\end{array}$} \\
\hline & & $N$ & $\%$ & $N$ & $\%$ \\
\hline \multirow{11}{*}{$\begin{array}{l}\text { General hospital } \\
\text { evaluation }\end{array}$} & $0=$ the worst & 0 & 0 & 0 & 0 \\
\hline & 1 & 0 & 0 & 0 & 0 \\
\hline & 2 & 4 & 1 & 0 & 0 \\
\hline & 3 & 7 & 1 & 4 & 2 \\
\hline & 4 & 7 & 1 & 13 & 7 \\
\hline & $5^{*}$ & 26 & 5 & 20 & 11 \\
\hline & 6 & 33 & 6 & 12 & 7 \\
\hline & 7 & 61 & 11 & 25 & 14 \\
\hline & 8 & 120 & 23 & 45 & 25 \\
\hline & $9^{* \star}$ & 115 & 21 & 23 & 13 \\
\hline & $10=$ the best ${ }^{\star *}$ & 172 & 31 & 38 & 21 \\
\hline \multirow{4}{*}{$\begin{array}{l}\text { Hospital } \\
\text { recommendation }\end{array}$} & Definitely not & 7 & 1 & 0 & 0 \\
\hline & Probably not** & 25 & 5 & 20 & 11 \\
\hline & Probably yes & 213 & 39 & 78 & 43 \\
\hline & Definitely yes ${ }^{\star}$ & 305 & 55 & 82 & 46 \\
\hline Total & $N=730$ & 550 & 75 & 180 & 25 \\
\hline
\end{tabular}

* - difference statistically significant with the value of $p<0.05,{ }^{* *}$ - difference statistically significant with $p \leq 0.01$

Other aspects of nursing care being subject to evaluation involved: communication with patients, explaining guidelines of new medications, explaining possible side effects.

Nurses always explained to patients working of new medication both in hospitals with the certificate and without the certificate (39\% each). In the opinion of $28 \%$ of respondents in hospitals with the certificate and $27 \%$ of respondents in hospitals without the certificate, nurses usually explained guidelines of a new medication. They never explained working of a new medication according to $17 \%$ of respondents in hospitals without the certificate and $15 \%$ of respondents in hospitals with the certificate. According to the most numerous group of patients (42\% in hospitals without the certificate and 31\% in hospitals with the certificate), nurses never explained side effects of medications $(p=0.013)$. Less numerous groups $(30 \%$ of people in hospitals with the certificate and $21 \%$ in hospitals without the certificate) stated that nurses always explained side effects of medication $(p=0.026)$ (Figure 1D).

According to $35 \%$ of respondents in hospitals with the certificate and $29 \%$ in hospitals without the cer- tificate, the level of information obtained about medications was sufficient. Communication about medication was evaluated as bad by $25 \%$ of patients in hospitals without the certificate and $22 \%$ in hospitals with the certificate.

Effective pain therapy was administered always according to $85 \%$ of respondents in hospitals without the certificate and $84 \%$ of respondents in hospitals with the certificate. In the opinion of $13 \%$ of patients in hospitals without the certificate and $12 \%$ of people in hospitals with the certificate, pain management therapy was usually efficient. Sparse group (4\% of respondents in hospitals with the certificate and $2 \%$ of respondents in hospitals without the certificate) stated that pain management therapy was sufficient occasionally.

According to $85 \%$ of respondents in hospitals with the certificate and $81 \%$ in hospitals without the certificate, all was done to reduce patients' pain. However, bad pain management was evaluated by $2 \%$ of respondents in hospitals with the certificate and $1 \%$ of respondents in hospitals without the certificate.

Patients' satisfaction with health services received were also hygiene and noise levels on the ward. A larger 
Table 4. Differences in patients' evaluation of particular subscales in the two types of hospitals

\begin{tabular}{|c|c|c|c|}
\hline \multirow[t]{2}{*}{ Characteristics/subscales } & \multirow{2}{*}{$p$ value } & $\begin{array}{l}\text { Hospitals without } \\
\text { the certificate }\end{array}$ & $\begin{array}{l}\text { Hospitals with } \\
\text { the certificate }\end{array}$ \\
\hline & & \multicolumn{2}{|c|}{ Level of characteristic } \\
\hline Nursing services & $<0.001 *$ & Lower & Higher \\
\hline Nurses communication & ns & - & - \\
\hline Communication about medication & ns & - & - \\
\hline Pain management & ns & - & - \\
\hline Patient's environment & $<0.001^{*}$ & Lower & Higher \\
\hline General health & ns & - & - \\
\hline Education & ns & - & - \\
\hline Reduced mobility & $0.03^{*}$ & Lower & Higher \\
\hline Age & ns & - & - \\
\hline Hospital evaluation & $<0.001^{*}$ & Lower & Higher \\
\hline
\end{tabular}

* - differences statistically significant $(p<0.05), n s-$ no difference statistically significant $(p \geq 0.05)$

group of respondents in hospitals with the certificate (70\%) than in hospitals without the certificate (59\%) thought than their rooms and sanitary equipment were of an acceptable level of cleanliness $(p=0.004)$. According to $35 \%$ of respondents in hospitals without the certificate and $25 \%$ in hospitals with the certificate, rooms and bathrooms were usually of an acceptable level of cleanliness $(p=0.003)$. Only sometimes rooms were clean in the opinion of $5 \%$ of respondents in hospitals without the certificate and $4 \%$ of patients in hospitals with the certificate $(p=0.005)$. One per cent of respondents said their rooms and bathrooms were never clean (Figure 1E).

Nocturnal silence was always ensured according to $56 \%$ of patients in hospitals with the certificate and $40 \%$ of respondents in hospitals without the certificate $(p<0.001)$. Less numerous group ( $42 \%$ of respondents in hospitals without the certificate and 36\% in hospitals with the certificate) usually did not enjoy silence during night hours. Only sometimes there was silence during night hours according to $14 \%$ of respondents in hospitals without the certificate and $7 \%$ in hospitals with the certificate $(p<0.001)$. For $4 \%$ of people in hospitals without the certificate and $1 \%$ in hospitals with the certificate, there never was silence during the night ( $p=0.027$ ) (Figure 1F).

More numerous group of patients in hospitals with the certificate (88\%) than in hospitals without the certificate $(79 \%)$, evaluated as good their environmental hygiene. Table 3 shows patients' evaluation of hospitals. The most numerous group in hospitals with the certificate (31\%) evaluated its hospital as " 10 " on a scale from 1 to 10 , whereas the largest group in hospitals without the certificate (25\%) evaluated its hos- pital as " 8 " on the same scale. Difference important statistically from answers given to questions about evaluating hospitals emerged with the evaluation of "5" ( $p=0.012)$, "9" ( $p=0.008)$, and " 10 " ( $p=0.005)$. Larger group of studied patients from hospitals with the certificate (55\%) than from hospitals without the certificate $(46 \%)$ definitely would recommend their hospitals to friends ( $p=0.011)$. Forty-three percent of respondents in hospitals without the certificate and 39\% of respondents in hospitals with the certificate, would probably or certainly recommend their hospital to others. One per cent of respondents with the certificate would definitely not recommend their hospital. Probably will not recommend their hospital $11 \%$ of respondents in hospitals without the certificate and $5 \%$ of patients in hospitals with the certificate $(p<0.001)$.

Patients' perceptions regarding nursing care had influenced their hospital evaluation.

Demonstration of good evaluation of hospitals by patients was associated with demonstration of high level of nursing services, nursing communication and patients' environment in both types of hospitals. Statistical analysis showed the same correlation ( $p<0.001)$ for nursing services, nursing communication, and patients' environment in both hospitals without the certificate and with the certificate. Correlation important statistically was determined for hospitals with the certificate in case of medication and pain management communication ( $p<0.001$ each). In the case of hospitals without the certificate for above mentioned characteristics, similarities were ascertained; however, they proved to be of lesser significance (communication about medication $p=0.027$, 
Table 5. Correlation statistics between subscales relating to care and hospital evaluation for which level of statistic importance of $p<0.05$ was noted

\begin{tabular}{|lcc|}
\hline Characteristics/subscales & Hospitals without the certificate & Hospitals with the certificate \\
\cline { 2 - 3 } Nursing services & Hospital evaluation & Hospital evaluation \\
Nurses communication & $<0.001^{* *}$ & $<0.001^{\star *}$ \\
Communication about medication & $<0.001^{* *}$ & $<0.001^{\star *}$ \\
Pain management & $0.027^{*}$ & $<0.001^{\star *}$ \\
Patient's environment & $0.036^{*}$ & $<0.001^{\star *}$ \\
General health & $<0.001^{* *}$ & $<0.001^{\star *}$ \\
Education & $0.006^{*}$ & $0.026^{*}$ \\
Limited mobility & $\mathrm{ns}$ & $0.017^{\star}$ \\
Gender & $0.005^{*}$ & $\mathrm{~ns}$ \\
Age & $<0.001^{* *}$ & $\mathrm{~ns}$ \\
\hline
\end{tabular}

${ }^{*}$ - level of significance of $p<0.05,{ }^{* *}$ - levels of statistical significance of $p<0.001, n s-$ no statistical significance $(p \geq 0.05)$

pain management $p=0.036)$. General health condition of patients in hospitals without the certificate shows much higher statistic importance $(p=0.006)$ than in hospitals with the certificate $(p=0.026)$. In hospitals with the certificate, correlation important statistically was shown between hospital evaluation and a patient's education $(p=0.017)$. In hospitals without the certificate, patients' restricted mobility had a significant influence on evaluating the hospital $(p=0.005)$. In hospitals without the certificate, an important correlation was demonstrated between patients' sex and hospital evaluation $(p<0.001)$. Patients' age displayed correlation both in hospitals without the certificate $(p=0.026)$ and in the hospitals with the certificate $(p=0.015)$. Correlations between subscales relating to care and hospital evaluation are illustrated in Table 4.

Demonstration of good hospital evaluation by patients was accompanied by high level of pain management in hospitals with the certificate $(75 \%, p<0.001)$ and in hospitals without the certificate (63\%), and high level of patients' environment in hospitals with the certificate $(79 \%)$ and in hospitals without the certificate $(67 \%, p<0.001)$. Other indications were not statistically significant.

Patients, in case of both types of hospitals, regardless of their age, evaluated hospitals good, but the biggest group of patients belonged to the age range of 50-64 years old. Average evaluation to hospitals without the certificate was given by $8 \%$ of patients from the age range 50-64 years old and 9\% of patients from the age range 65-80 years old.

In order to verify hypothesis regarding differences in evaluation of hospitals with and without the cer- tificate and subscales made by patients, the MannWhitney's test was used (Table 5).

Analysis of the results demonstrated higher level of nursing care based on the particular subscales in hospitals with the certificate than in hospitals without the certificate. Statistically important difference was observed in two subscales: nursing services $(p<0.001)$ and patients' environment $(p<0.001)$. For the remaining subscales, differences were statistically irrelevant. With regards to limited mobility, statistically significant difference was at the level of $p=0.03$ and for hospital evaluation at $p<0.001$, and was higher for hospitals with the ISO certificate.

\section{Discussion}

In modern healthcare management, high quality of health services and safe environment for both the patients and the staff are of great importance, as well as hospital good image.

The patient has a right to safe care that is high quality of services rendered, especially during treatment of surgery, which involves unpleasant sensations and experiences. The strongest sensation before and after the surgery is pain and mobility restrictions, preventing patient from satisfying his basic needs. Level of patients' and their family's satisfaction depended on: the way patient was treated, quality of care received, speed of services, prospect of receiving information about medication, communication, rooms appearance, and hygiene. Patients' perception of care received, which is influenced by personal expectations, values, and previous experience, is of deeply emotional and subjective character. Patient staying in a hospital observes and remembers a lot of details like 
staff behavior, and reactions that he encounters during his hospitalization, which in turn influence his feelings. Patients' negative feelings may additionally be enhanced by bad health, lack of health improvement, not understanding medical terminology, unpleasant room and bathroom appearance, and by unpleasant atmosphere [16]. Own research results showed that about $70 \%$ of patients were pleased with treatment. Patients were more satisfied with promptitude of assisting them with the need for defecation in hospitals with the certificate $(75 \%)$ than in hospitals without the certificate (61\%). Nurses' reaction after pressing the buzzer was quick in opinion of $56 \%$ of patients in hospitals with the certificate and in 34\% in hospitals without the certificate. In the research of Smolinska et al., patients also evaluated promptness of staff reaction to their problems as high [17]. Overall evaluation of patients' satisfaction with quality of nursing care in both types of hospitals trended at a high level. Good evaluation was given by $93 \%$ of respondents in hospitals with the certificate and $89 \%$ of respondents in hospitals without the certificate. Mann-Whitney's test proved statistically significant difference between the two types of hospitals at the level of $p<0.001$ showing the benefit for the hospitals with the certificate. Results of Wasilewski's research also showed high and average level of satisfaction from nursing services [12]. Pearson's $\chi^{2}$ test demonstrated strong statistic correlation between quality of rendered nursing services and hospital evaluation made by the patient $(p<0.001)$. Good hospital evaluation was accompanied by high quality of services in both types of hospitals. Scope of nursing communication influenced patient's sense of security by providing him with information, explanations, and comforting words. In case of not receiving this information form a nurse, patient was turning to another patient, who rarely could give correct answers. This status quo raises concerns. Nurses' communication not only provides patients with the right information, but also is a mean of personal engagement and way of obtaining patients' cooperation and reducing fear. Through communication, unpleasant sensations during treatment are reduced in the moment of giving explanation. Members of staff must know how to communicate effectively and how to work as a team. Lack of proper communication within the team is the reason for making mistakes [18, 19]. Our study shows that about $70 \%$ of patients evaluated communication with nurses as good.

Patients expressed low evaluation of their dissatisfaction from hearing wrong information and bad communication about medications. None of the medications are free from side effects. Patients wants to know more about medications they take, and wants to have bigger control over the way they are being treated. According to Eurobarometer's research, 23\% of respondents claimed that either them or members of their family suffered from mistakes in pharmaceutical treatment [20]. Good evaluation for communication about medication was given by only $35 \%$ of patients in hospitals with the certificate and 29\% of respondents in hospitals without the certificate. Respondents' studied by Lyu had better results (59\%) [21]. In the research of Baczyk et al., nursing care level in the scope of communication received the lowest score and was close to the lowest value, which confirms proper nursing care [22]. Patients' satisfaction with pain management reached high level. Staff in both types of hospitals effectively reduced pain with kindness, understanding, empathy, providing peace and quiet, pain monitoring, and easing somatic symptoms. In Bączyk's research, the values were similar and oscillated around high. In Juszczak et al., the values were lower [19].

Important element providing patients' safety and good quality of nursing care is maintaining room cleanliness. Controlling current cleanliness of patients' environment and carrier state of pathogenic micro-organisms among the staff members is an efficient way of preventing hospital infections. Numerous group of patients form hospitals with the certificate $(88 \%)$ and from hospitals without the certificate (79\%) evaluated hospital cleanliness as good. Data analysis showed correlation between good hospital evaluation by patients and good evaluation of patients' environment. Many researchers evaluated standard of nursing care as high [11, 23-25]. Patient is expecting effective care at a high level, meeting all of his expectations and sense of security. Not meeting patients' expectations will have effect on shaping patients' opinion and satisfaction. We cannot then talk about quality without patients' satisfaction. Ever more frequently, when choosing a health institution, a decision is based on the quality of services provided. In Poland, the National Health Found implemented solutions that prefer institutions holding the quality management systems. More and more often companies start to buy packages for their employees form the institutions with the high reference for healthcare services [26].

Systematic evaluation of quality of nursing care and healthcare are challenging for all health institutions and conduce to improve the whole system.

\section{Conclusions}

1. Award of the certificate to the hospital had influenced the results received from patients regarding the evaluation of nursing care.

2. Quality of nursing care in the subscales: nursing services, nurses' communication, pain management and patients' environment were evaluated as good by most of the respondents. The lowest rating was received by subscale "communication about medi- 
cation". This indicates need for monitoring and continuous improvement in quality of nursing care.

3. From the service-receiver stance, we could gain information about strengths and weaknesses of nursing care. Main fields of quality of nursing care that, according to the respondents, would need improving concern patients' access to information about how the new medication works and what are the possible side effects.

4. Introduction of quality management systems improves quality of nursing care and provision of other services in healthcare facilities.

\section{Conflict of interest}

The authors declare no conflict of interest.

\section{References}

1. Ostrowska K. System zarządzania jakością zgodny z wymogami ISO 9001-2000 - o tym trzeba wiedzieć. In: ISO 9001 - skuteczny sposób uzyskania certyfikatu jakości. Kreier E, Łuczak J (eds.). Wydawnictwo Forum Sp. z o.o. Poznań 2004; 174-185.

2. Buchelt B. Znaczenie kierowników liniowych w zarzadzaniu zasobami ludzkimi na przykładzie wybranych procesów realizowanych przez współczesne organizacje. Problemy Zarządzania 2008; 22: 57-73.

3. Mitchell PM. Defining Patient Safety and Quality Care. In: Patient Safety and Quality: An evidence-based handbook for nurses. Hugnes RG (ed.). Agency for Healthcare Research and Quality (AHRQ), Rockvile 2008; 2-10.

4. Sierpińska L. Proces wdrożenia systemu zarządzania jakością w szpitalu. Problemy Pielęgniarstwa 2008; 16: 401-404.

5. Opolski K, Dykowska G, Możdżonek M. Zarządzanie przez jakość w usługach zdrowotnych. Cedewu, Warszawa 2009.

6. Sielska J, Wieja E, Głowacka MD. Badania satysfakcji pacjenta jako przejaw orientacji na klienta w systemie zarządzania jakością. Pielęgniarstwo Polskie 2009; 1: 25-31.

7. Kulikowski J, Wójcik B. Który system oceny zewnętrznej wybrać: akredytację czy ISO? Zdrowie i Zarządzanie 2003; 5: 34.

8. Piątek A. Standardy praktyki w zawodach pielęgniarki i położnej. In: Podstawy organizacji pracy pielęgniarskiej. Podręcznik dla studentów studiów licencjackich Wydziału Pielęgniarstwa oraz Wydziału Nauk o Zdrowiu. Ksykiewicz D, Czelej A (eds.). Wydawnictwo Czelej, Lublin 2004; 185-205.

9. Kózka M. Zastosowanie badań naukowych w praktyce zawodowej pielęgniarki. In: Procedury Pielęgniarskie. Kózka M, Płaszewska-Żywko L (eds.). Wydawnictwo Lekarskie PZWL, Warszawa 2009; 21-24.

10. Thi PLN, Briancon S, Empereur F, Guillemin F. Factors determining in patient satisfaction with care. Social Sci Med 2002; 54: 493-504.

11. Sierpińska L, Dzirba A. Poziom satysfakcji pacjenta z opieki pielęgniarskiej na oddziałach zabiegowych. Pielęgniarstwo Chirurgiczne i Angiologiczne 2011; 1: 18-22.

12. Wasilewski TP. Subiektywna ocena wybranych aspektów satysfakcji z pobytu w szpitalu pacjentów oddziałów zabiegowych. Pielęgniarstwo Chirurgiczne i Angiologiczne 2008; 2: 81-86.
13. Kapała W, Chudziński S, Hyrcza S. Oczekiwania pacjentów hospitalizowanych na oddziałach zabiegowych wobec personelu pieleggniarskiego. Pieleggniarstwo Chirurgiczne i Angiologiczne 2008; 2: 12-18.

14. Ozga D, Binkowska-Bury M. Ocena satysfakcji pacjenta z opieki pielęgniarskiej na oddziale szpitalnym. Polski Przegląd Nauk o Zdrowiu 2008; 4: 298-303.

15. Kózka M. Procedury jako element jakości opieki zdrowotnej. In: Procedury pielęgniarskie. Kózka M, Płaszewska-Żywko L (eds.). Wydawnictwo Lekarskie PZWL, Warszawa 2009; 25-28.

16. Rżewska I. Pacjent - Pielęgniarka. Istytut Wydawniczy Związków Zawodowych, Warszawa 1987.

17. Smolińska A, Marciniak M, Ślusarz R, Królikowska A, Jabłońska R, Książkiewicz B. Poziom satysfakcji z usług medycznych na oddziale neurologii. Udar mózgu. Problemy Interdyscyplinarne 2008; 10: 76-82.

18. Rosentein AH, O'Daniel M. A Survey of the Impact of Disruptive Behaviors and Communication Defects on Patient Safety. Jt Comm J Qual Patient Saf 2008; 34: 464-471.

19. Juszczak K, Jaracz K, Kuberka I. Subiektywna ocena jakości opieki pielęgniarskiej w aspekcie bólu pooperacyjnego u chorych poddanych interwencji chirurgicznej. Pielęgniarstwo Chirurgiczne i Angiologiczne 2016; 4: 127-130.

20. Raport z badania Eurobarometer: „Medical Errors”. Availableat:ec.europa.eu/health/patient_safety/adverse_events/ eurobarometer/index_eu.thm.

21. Lyu H, Wick EC, Housman M, Freischlag JA, Makary MA. Patient Satisfaction as a Possible Indicator of Quality Surgical Care. JAMA Surg 2013; 148: 362-367.

22. Bączyk G, Ochmańska M, Stępień S. Subiektywna ocena jakości opieki pielęgniarskiej w zakresie bólu pooperacyjnego u chorych leczonych chirurgicznie. Problemy Pielęgniarstwa 2009; 17: 173-177.

23. Al-Abri R, Al-Balushi A. Patient satisfaction survey as a tool towards quality improvement. Oman Med J 2014; 29: 3-7.

24. Kalinowski P, Bojakowska U. Ocena satysfakcji z opieki pielęgniarskiej wśród pacjentów po operacji zaćmy w prywatnej klinice okulistycznej. Problemy Pielęgniarskie 2013; 21: 173-178.

25. Mohanan K, Kaur S, Das K, Bhalla A. Patient satisfaction regarding nursing care at Emergency Outpatient Department in a Tertiary Care Hospital. J Mental Health Human Behavior 2010; 15: 54-58.

26. Wroński K, Bocian R. Dlaczego Zakłady Opieki Zdrowotnej powinny badać satysfakcję pacjentów $\mathrm{z}$ oferowanych przez siebie usług medycznych? Pielęgniarstwo Chirurgiczne i Angiologiczne 2009; 4: 127-130.

\section{Address for correspondence:}

Jozefa Czarnecka, MSc, PhD

Warsaw Medical University

Faculty of Health Sciences

27 Ciolka St.

01-445 Warsaw, Poland

Phone: +48 663647275

Email: j.czarnecka@wp.pl 